\title{
Haemorrhagic enteritis associated with parvovirus B19 following hematopoietic stem cell transplantation: a case report and literature data
}

\author{
Oleg V. Goloshchapov ${ }^{1}$, Natalia D. Ventslovayte ${ }^{1}$, Ruslana V. Klementeva ${ }^{1}$, Alexander N. Shvetsov ${ }^{1}$, \\ Aleksandr A. Shcherbakov ${ }^{1}$, Maria O. Goloshchapova ${ }^{1}$, Vadim E. Karev ${ }^{2}$, Boris V. Afanasyev ${ }^{1}$ \\ ${ }^{1}$ Raisa Gorbacheva Memorial Research Institute of Pediatric Oncology, Hematology and Transplantation, Pavlov University, \\ St. Petersburg, Russia \\ ${ }^{2}$ Federal Pediatric Research Center of Infectious Diseases, St. Petersburg, Russia
}

Dr. Oleg V. Goloshchapov, Raisa Gorbacheva Memorial Research Institute of Pediatric Oncology, Hematology and Transplantation, Pavlov University, L. Tolstoy St. 6-8, 197022, St. Petersburg, Russia

Citation: : Goloshchapov OV, Ventslovayte ND, Klementeva RV et al. Haemorrhagic enteritis associated with parvovirus B19 following hematopoietic stem cell transplantation: a case report and literature data. Cell Ther Transplant 2019; 8(4): 57-61.

\section{Summary}

Parvovirus (PV) B19 infection is rather spread worldwide and manifests with a range of clinical symptoms. The aim of our report was to demonstrate a rare case of haemorrhagic enteritis associated with parvovirus B19 in the patient after allogeneic hematopoietic stem cell transplantation (allo-HSCT).We present here a clinical case of PV infection which proceeded as acute haemorrhagic enteritis in 52-year male patient who underwent HSCT. Distinct expression of antigens specific for PV B19 was revealed on autopsy by means of immunohistochemical testing, along with PVB19 DNA found in stomach, small intestine tissues and myocardial samples by means of PCR technique.
Phone: +7 (921) 9792913

E-mail: golocht@yandex.ru

\section{Introduction}

Incidence of parvovirus B19 (PVB19) infections is registered everywhere in the world, with specific antibodies detectable in $70-75 \%$ of adult population $[1,2]$. In immunocompetent persons, the PVB19 infection typically manifests as infectious erythema or arthropathy [2, 3, 4]. In certain cohorts, however, this infection may proceed as a severe disorder, e.g., in hematological patients where it may cause aplastic

\section{Keywords}

Parvovirus B19, allogeneic hematopoietic stem cell transplantation, clinical infection, haemorrhagic enteritis, myocarditis, intestinal bleeding. 
(HSCT). The patient manifested with severe enteric bleeding resistant to common hemostatic therapy. Upon autopsy, the PVB19-specific antigens were detected, along with virus-specific nucleotide sequences revealed in gastric, enteric and myocardial samples.

\section{Case report}

A male patient, 52, was admitted to the clinic of R. Gorbacheva Memorial Institute with previously diagnosed chronic myeloid leukemia (Ph-). Standard virological examination of both donor and patient was performed before the HSCT, according to the institutional protocol. IgG antibodies to cytomegalovirus, Epstein-Barr virus, Herpes simples type 1 and 2 were detected in blood sera, along with negative serological tests for HBV, HCV and AIDS virus. Relatives of the patient has provided a written informed consent for the publication of his personal medical data.

The patient received Ruxolitinib therapy with evident clinical improvement. Therefore, a decision of allogeneic HSCT was approved. Upon admission, clinical blood analysis showed hypochromic anemia (ery, $3.3^{\star} 10^{12} / \mathrm{L}$; Hb, $86 \mathrm{~g} / \mathrm{L}$; platelets, $\left.77^{\star} 10^{9} / \mathrm{L}\right)$. Myeloablative conditioning regimen was applied pre-transplant, i.e., Fludarabine $(50 \mathrm{mg} / \mathrm{d})$, Busulfan (344 $\mathrm{mg} / \mathrm{d}$ ), Ruxolitinib (45 mg/d). The patient tolerated well the therapy, and no signs of active infection were observed at the time of HSCT.

Hematopoietic transplantation from a related donor was performed on D0. The graft parameters were as follows: total volume of $352 \mathrm{~mL}$ containing $94.4 \times 10^{9}$ nucleated cells (10.9 $\times 10^{8} / \mathrm{kg}$ body mass); CD34+ cells, $0.92 \%\left(10.0 \times 10^{6} / \mathrm{kg}\right)$; CD3+ cells, $21.9 \%\left(23.9 \times 10^{7} / \mathrm{kg}\right)$.

Since the day $+1(D+1)$, the first-line antibiotics were administered, due to ongoing febrile neutropenia (Cefoperazon + Sulbactam, $1 \mathrm{~g}+1 \mathrm{~g}$ twice a day). Immunosuppressive therapy was also started: Cyclophosphfan $4500 \mathrm{mg} /$ day (D+3 to $\mathrm{D}+4)$ followed by Ruxolitinib since D+5 (15 mg daily).

Since D+10, a negative clinical trend, i.e., development of grade 3 oral mucositis was observed, thus requiring administration of opioid analgetics (Fentanyl infused at $0.5 \mathrm{mg} / \mathrm{kg} / \mathrm{h}$ ). The signs of haemorrhagic syndrome appeared as petechial rush on skin and mucosae, along with periodical nasal bleedings. The patient was administered parenteral nutrition. Vancomycin (500 mg, $4 \times$ daily) was added to basic antibacterial therapy, due to increased serum C-reactive protein levels.

Clinically, the patient's state remained moderately severe on $\mathrm{D}+11$ to $\mathrm{D}+14$, with persisting trilineage cytopenia, pronounced haemorrhagic signs on the skin and oral mucosa, and daily requirements for blood components. Mucositis symptoms were gradually resolved since $\mathrm{D}+15$, thus allowing unaided peroral nutrition.

By the day +17 , a febrile fever episode with chills was successfully cured with antipyretics. However, an increase in general fatigue was observed during subsequent hours accompanied by repeated fever attack with chills, followed by the bile vomiting with blood admixture. Therefore, Vancomycin treatment has been changed to Linezolid (600 mg twice daily); Cefoperazon + Sulbactam therapy was changed to Meropenem ( $1 \mathrm{~g}$ twice daily). Immunosuppressive treatment by Ruxolitinib was also discontinued.

On $\mathrm{D}+18$, the body temperature was sub-febrile, pale skin, general fatigue, disorientation. Clinical blood analysis showed a decreased $\mathrm{Hb}$ by $20 \mathrm{~g} / \mathrm{L}$, despite erythrocyte mass transfusion (2 doses). Gastroabdominal bleeding was suspected. The patient was delivered to ICU due to instable hemodynamics (blood hypotension to $75 / 45 \mathrm{~mm} \mathrm{Hg}$ ), thus requiring sympathomimetic drugs at moderate doses, i.e., noradrenaline $(0.04 \mathrm{mcg} / \mathrm{kg} / \mathrm{min})$. Urgent fibrogastrocopy has revealed erosive esophagitis and gastritis. We were unable to determine the source of bleeding. The signs of continuous bleeding were traceable on Day +19 , i.e., dark, melena-like stool with blood clots, at a daily volume of 4 liters. Conservative hemostatic therapy (transfusion of blood components, fresh-frozen plasma, cryoprecipitate, Prothromplex (2400 U daily), antifibrinolytic drugs, aminomethylbenzoic acid (100 mg $3 \times$ daily), Terlipressine ( $1 \mathrm{mg} 4 \times$ a day) was not effective, with blood $\mathrm{Hb}$ levels reaching $25 \mathrm{~g} / \mathrm{L}$ without any changes. The patient was intubated in order to perform artificial lung ventilation.

Computer tomography of abdominal area with Optiray contrast was performed, yielding no evidence of gastrointestinal bleeding. Fibrocolonoscopy was also made, however, without any findings suggestive for hemorrhage sources: the colic walls along their entire length were covered with blood-impregnated mucinous secretions. Due to absence of evident colon bleeding accompanied by blood clots in the colon lumen and diffuse blood distribution, we suggested a small intestinal bleeding in this case.

By the $D+20$, the clinical state remained extremely severe and unstable, due to continuing hemorrhage treated with massive conservative hemostatic therapy and inotropic support (epinephrine infused at $0.05 \mathrm{mg} / \mathrm{kg} / \mathrm{min}$ ).

Despite high probability of surgical intervention, due to recurrent bleeding and anemia progression, we still decided to perform a laparotomy aiming or detection of the bleeding source and achieving surgical hemostasis. Upon revision of abdominal cavity, the small intestine in its upper third and more distal part was found to be filled with blood masses. No visible pathological changes were found during the inspection and palpatory revision of small intestine. After passing the Treitz ligament with fibrogastroscopic probe, a number of acute mucosal erosions have been revealed that were covered with hematin and sometimes with blood clots (Fig. 1). During this surgical intervention, 8 to 10 such loci were closed by sutures. The following conclusion was drawn after the laparotomy: Erosive esophagitis; acute erosive haemorrhagic gastritis; Continuous bleeding from the jejunal erosions.

On the D+21, no sufficient dynamics was observed and ALV was continued. Stable febrile fever persisted without any response to antipyretics; hemodynamics was supported by norepinehrine $(0.06 \mathrm{mcg} / \mathrm{kg} / \mathrm{min})$. Stool was absent, with haemorrhagic secretion from the surgical wound $(520 \mathrm{~mL})$. Blood $\mathrm{Hb}$ level remained stably low. On day+22, the patient had dark stool with bloot clots. On day +24 , the patient developed pronounced negative symptoms associated with 
continuing intestinal bleeding (blood admixture in stool, blood Hb drop by $35 \mathrm{~g} / \mathrm{L}$ within 12 hours, followed by haemorrhagic shock that was refractory to vasopressor drugs, infusion therapy by salt solutions and substitution hemotransfusions. The patient entered terminal phase with arrested blood flow and no effect from resuscitation measures.
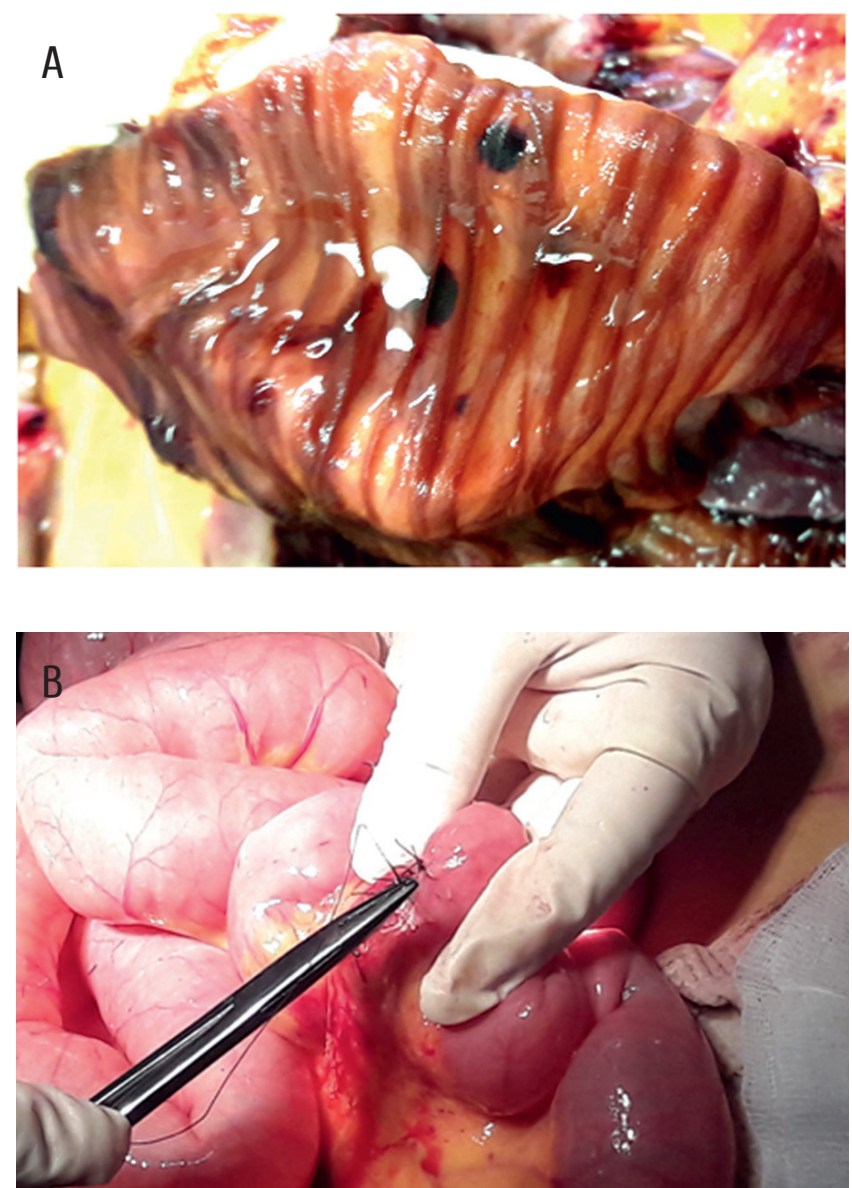

Figure 1. Images obtained at surgical intervention of the patient with GIT bleeding

A - Macroscopic view of the small intestinal wall: multiple focal hemorrhages with distinct contours $(0.2$ to $0.8 \mathrm{~cm}$ in size) protruding to the lumen are visible in the intestinal wall, mucosae are also showing erosive defects up to $0.3-0.4 \mathrm{~cm}$ (shown by arrow).

$\mathrm{B}$ - Closing of a bleeding source with single sutures when the gastroscope was passed behind the Treitz ligament.

Upon postmortem pathological examination, large amounts of blood are seen in enteric and colonic lumen, along with numerous hemorrhages and erosions on the jejunal mucosa. Upon histological examination, the signs of altered blood flow in the large bowel were evident, i.e., macrofocal, partly confluent heporrhages to submucous layers of intestinal wall, as well as in myocardium as extended confluent perivascular and perimuscular hemorrhages without pronounced perifocal cellular infiltration (Fig. 2 A, C). Mucosal epithelium of the large bowel was desquamated along the whole length, mostly affecting superficial layers of mucosa, and its stroma showed extensive infiltration with polymorphic cells. In the myocardium, perivascular pathological cellular infiltration was weakly pronounced. Immunohistochemical studies have shown expression of parvovirus B19 antigen revealed in stromal elements of intestines and myocardium (Fig. 2, B, D).
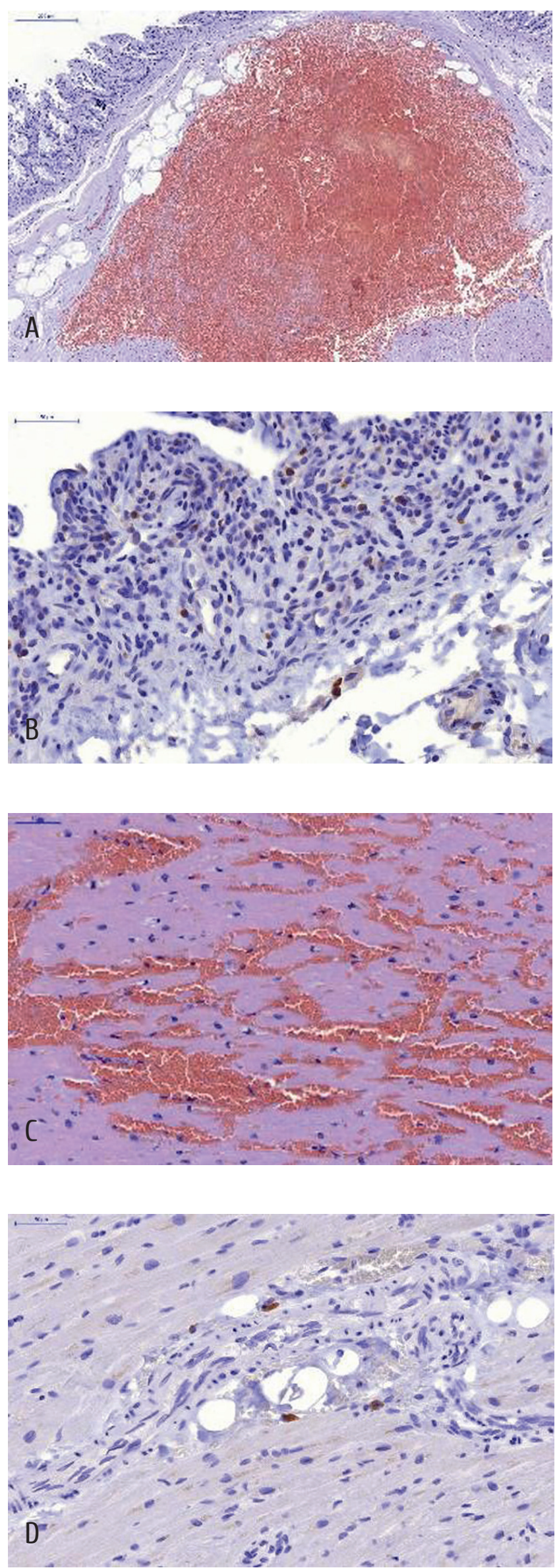

Figure 2. Postmortem signs of generalized parvovirus infection

Hematoxilin/eosin staining (A, C); immunohistochemical (IHC) labeling for parvovirus B19, DAB staining (B, D). 
Macrofocal hemorrhage to the submucosal areas of jejunal, extended perimuscular myocardial hemorrhages (B). Expression of PVB19 antigens (brown staining) in stromal cells of the large intestinal mucosa and myocardium (arrows). The histological slices were prepared from the paraffin-embedded specimens. Immunohistochemistry was carried out with murine monoclonal antibodies to PVB19 (Novocastra, UK, 1:10 dilution). The cells were examined with Ultra Vision Quanto polymerization system, Thermo, USA).

We have performed a study of autoptic material by means of PVB19 antigen expression detected by immunohistochemistry. Real-time PCR of DNA extracted from tissues has revealed parvovirus $\mathrm{B} 19$ in jejunum at $6.7 \times 10^{3} \mathrm{MU} / \mathrm{mL}$, in stomach, $3.5 \times 10^{3} \mathrm{MU} / \mathrm{mL}$, in large bowel samples, at $1.3 \times 10^{3} \mathrm{MU} / \mathrm{mL}$, for myocardium, $1.1 \times 10^{3} \mathrm{MU} / \mathrm{mL}$, with negative results for blood samples.

\section{Discussion}

As mentioned above, the issues of parvovirus infection is especially important in immunocompromised patients who underwent hematopoietic stem cell transplantation $[2,11]$. The endogenous virus reactivation may occur following immunosuppressive therapy. Requirements for multiple hemotransfusions may also significantly increase the infection risk $[12,13,14,15]$. Moreover, an opportunity exists for a viral transmission from donors during allogeneic HSCT [13].

In the patients with pronounced immune deficiency, one may observe severe non-typical clinical condition affecting liver, kidney, myocardium, central nervous system being at high risk for lethal outcome $[3,8,9,10]$.

Affection of gastrointestinal tract (GIT) is not typical to HPVB19 infection. There are only two clinical cases reported in literature with intestinal detection of the virus. E.c., Loris Pironi, Francesca Bonvicini have revealed PVB19 in the intraepithelial intestinal $\mathrm{T}$ lymphocytes in a 52-year male patient with suggested nonspecific ulcerous colitis who developed severe symptoms during immunosuppressive therapy [16]. The second case of haemorrhagic enteritis caused by PVB19 was described by H. Koklu, B. Buyukeren in a 63year old female patient with aplastic anemia in her history [17]. Both patients received therapy with intravenous immunoglobulins that yielded positive results, i.e., jugulation of symptoms and elimination of the virus $[16,17]$.

The reported clinical case is showing for the first time a case with atypical clinical course of parvovirus-associated infectious condition which proceeded as severe haemorrhagic enteritis in a patient treated with immunosuppressive drugs following allogeneic HSCT. Both donor and recipient of hematopoietic stem cells were not tested for PVD19 before transplant. Due to non-typical GIT affection in presence of parvovirus infection, our diagnostics did not initially include tests for PVB19. The patient underwent conventional examination for herpesvirus infection (CMV, EBV, HHV type 6, HSV), we have also excluded graft-versus-host disease (GvHD).

Upon the postmortem histological study of a myocardial sample, we have documented haemorrhagic myocarditis with perivascular lymphoid-cell infiltration, thus suggesting a parvovirus affection. Further on, PVD19 was detected by means of IHC and PCR in myocardium, stomach and intestinal tissues. Hence, distinct etiological verification of a lethal infectious pathology in the oncohematological patient was performed as late as by autopsy.

In conclusion, the reported clinical case demonstrates atypical clinical course of parvovirus infection proceeding as haemorrhagic enteritis in an immunocompromised patients after hematopoietic stem cell transplantation. GIT affection associated with parvovirus B19 seems to be a rather rare condition with severe clinical course, and it may result into serious complications including lethal outcome.

\section{Conflict of Interest}

The authors report no conflicts of interest.

\section{References}

1. Servant-Delmas A, Lefrère JJ, Morinet F, Pillet S. Advances in human B19 erythrovirus biology. J Virol. 2010; 84:9658-9665.

2. Laudry ML. Parvovirus B19. Microbiol Spectrum. 2015; 4(3):1-13.

3. Leon LA, Alves A, Garcia RC, Melgaço JG, de Paula VS, Pinto MA. Parvovirus infection in a fatal case of acute liver failure, Pediat Infect Dis J. 2017; 36(12):e355-e358.

4. Kerr JR. Pathogenesis of parvovirus B19 infection: Host gene variability, and possible means and effects of virus persistence. J Vet Med (Ser.B). 2005; 52(7-8):335-339.

5. Lotze U, Egerer R, Tresselt C, Gluck B Dannberg G, Stelzner A, Figulla HR. Frequent detection of parvovirus B19 genome in the myocardium of adult patients with idiopathic dilated cardiomyopathy, Med Microbiol Immunol, 2003; 193(2-3):75-82.

6. Lamparter S, Schoppet M, Pankweit S, Maisch B. Acute parvovirus B19 infection associated with myocarditis in an immunocompetent adult. Hum Pathol.2003; 34(7):725-728.

7. Nakamura Y, Ohsawa I, Goto Y, Namba H, Dodo Y, Tsuji M, Kiuchi Y, Inagaki M, Gotoh H. The impact of human parvovirus B19 infection on heart failure and anemia with reference to iron metabolism markers in an adult woman. Internal Medicine. 2018; 57(3):403-407.

8. Spartalis M, Tzatzaki E, Spartalis E, Damaskos C, Mavrogeni S, Voudris V. Parvovirus B19 myocarditis of fulminant evolution, Cardiol Res. 2017; 8(4):172-175.

9. Verdonschot J, Hazebroek M, Merken J, Debing Y, Dennert R, Brunner-La Rocca HP, Heymans S. Relevance of cardiac parvovirus B19 in myocarditis and dilated cardiomyopathy: review of the literature. Eur J Heart Failure. 2016; 18(12):1430-1441.

10. Samanta D, Willis E. Focal seizure associated with human parvovirus B19 infection in a non-encephalopathic child. World J Pediat. 2016; 12(1): 118-120. 
11. Sedaghat AR, Rastegar DA, O Connell K, Dinoso JB, Wilke CO, Blankson JN. Evaluation of parvovirus B19 infection in children with malignant or hematological disorders. Clin Infect Dis. 2010; 50(10):1425-1426.

12. Khamitova I, Lavrentyeva I, Averyanova M, Chukhlovin A, Zubarovskaya L, Afanasyev B. Parvovirus B19 incidence, specific antibody response, and delayed hematopoietic recovery after allogeneic hematopoietic stem cell transplantation. Cell Ther Transplant. 2018; 7(1):36-43.

13. Plentz A, Hahn J, Knoll A, Holler E, Jilg W, Modrow S. Exposure of hematologic patients to parvovirus B19 as a contaminant of blood cell preparations and blood products. Transfusion. 2005; 45: 1811-1815.

14. Gahr M, Pekrun A, Eiffert H. Persistence of parvovirus B19-DNA in blood of a child with severe combined immunodeficiency associated with chronic pure red cell aplasia. Eur J Pediat. 1991; 150(7): 470-472.
15. Trimble S, Parker C, Grant A, Soucie JM, Reyes N. Assessing emerging infectious threats to blood safety for the blood disorders community. J Prevent Med. 2010; 38 (Suppl 4): S468-S474.

16. Pironi L, Bonvicini F, Gionchetti P, D'Errico A, Rizzello F, Corsini C, Foroni L, Gallinella G. Parvovirus B19 infection localized in the intestinal mucosa and associated with severe inflammatory bowel disease. J Clin Microbiol. 2009; 47(5): 1591-1595.

17. Koklu H, Buyukeren B, Inkaya AC, Sokmensuer C, Kav T. An unexpected cause of acute enteritis in a patient with pure red cell aplasia parvovirus B19-associated acute enteritis. Am J Gastroenterol. 2018; 113(4): 630-632. 2018.

\title{
| Геморрагический энтерит, ассоциированный с парво- вирусом В19 после трансплантации гемопоэтических стволовых клеток: клинический случай и данные литературы
}

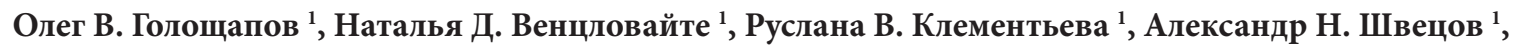 \\ Александр А. Щербаков ${ }^{1}$, Мария О. Голощапова ${ }^{1}$, Вадим Е. Карев ${ }^{2}$, Борис В. Афанасьев ${ }^{1}$ \\ ${ }^{1}$ НИИ детской онкологии, гематологии и трансплантологии им. Р. М. Горбачевой, Первый Санкт-Петербургский \\ государственный медицинский университет им. акад. И. П. Павлова, Санкт-Петербург, Россия \\ ${ }^{2}$ Федеральный детский научно-клинический центр инфекционных болезней, Санкт-Петербург, Россия
}

\section{Резюме}

Инфекция парвовирусом (ПВ) В19 весьма распространена в мире и проявляется рядом клинических симптомов. Целью нашего сообщения было описание редкого случая геморрагического энтерита, ассоциированного с ПВ В19 у пациента после аллогенной трансплантации гемопоэтических стволовых клеток (алло-ТГСК). Нами представлен клинический случай парвовирусной инфекции, протекавшей на фоне острого геморрагического энтерита у 52-летнего больного после ТГСК. Посредством иммуногистохимического тестирования выявлена экспрессия антигена ПВ В19- при аутопсии, а также с помощью ПЦР была обнаружена ДНК ПВ В19 в тканях желудка, тонкой кишки и образцах миокарда.

\section{Ключевые слова}

Парвовирус В19, аллогенная трансплантация гемопоэтических клеток, клиническая инфекция, геморрагический энтерит, миокардит, кишечное кровотечение. 